\title{
SOCIAL SOFTWARE, GROUPS, AND GOVERNANCE
}

\author{
Michael J. Madison*
}

2006 Mich. St. L. Rev. 153

TABle of Contents

INTRODUCTION ............................ 153

I. Social Software and Group Salience $\ldots \ldots \ldots \ldots \ldots \ldots$

II. The Virtues of Informal Groups . . . . . . . . . . . . . . . . . 164

A. Lawmaking Groups $\ldots \ldots \ldots \ldots \ldots \ldots \ldots \ldots$

B. Cognitive Groups $\ldots \ldots \ldots \ldots \ldots \ldots \ldots \ldots \ldots \ldots \ldots$

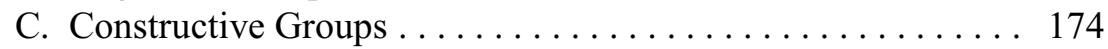

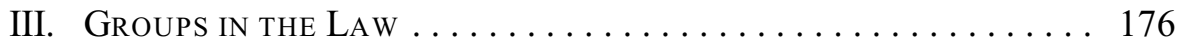

A. Finding Groups in the Law $\ldots \ldots \ldots \ldots \ldots \ldots \ldots \ldots \ldots$

B. Law and The Future of Groups $\ldots \ldots \ldots \ldots \ldots \ldots \ldots \ldots 1$

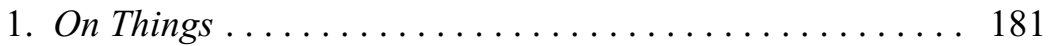

2. On Places ............................. 183

3. On Stories . . . . . . . . . . . . . . . . . . . . . . 186

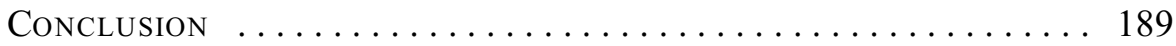

\section{INTRODUCTION}

The "personal computing" technology paradigm of the last twenty years has done much to expand the scope of individual agency in the context of law and policy. Computers help individuals to create and consume information at unprecedented scale and at unprecedented speed. That paradigm has also tended to suppress equivalent exploration of the possibilities of informal groups. This Essay points out some of those possibilities and illustrates how they may help us understand how and what law does and should regulate, using some relatively new technologies as points of departure. I characterize this as the problem of governance, and I look to groups to frame a solutionone based less on alternative constructions of conventional public regulation and more on blends of public and private, and individual and social. ${ }^{1}$

* Associate Professor, University of Pittsburgh School of Law. Earlier versions of this Essay were presented at the symposium on "Real Law, Online Rights" at the University of Virginia School of Law, and at the 2005 Annual Meeting of the Association for the Study of Law, Culture \& Humanities. Thanks to participants in those programs for thoughtful reactions and comments, and to Beth Noveck, Susan Crawford, Dan Hunter, Mike Carroll, Frank Snyder, Julie E. Cohen, and Jack Balkin for thoughtful criticism.

1. See Orly Lobel, Interlocking Regulatory and Industrial Relations: The Governance 
I set aside the premise that computers are particularly liberating for the individual. ${ }^{2}$ Instead, I offer an alternative premise. The social dimension of computing reminds us that computing is about people, not merely about information. ${ }^{3}$ Computing builds connections, networks, and pathways for information and activity, channels that constrain the individual and that enable the group. I argue that we should look for value in the social dimensions of computing; as matters of law and policy, therefore, we should look for ways to enhance-and, where appropriate, to limit-that social character.

Importantly, for law and policy there is little fundamentally different or unique about the technologies of groups. Yet, technology serves as an important element in my re-framing of regulatory focus. I use the introduction of the Macintosh computer in 1984 to signify the beginning of true "personal" computing, that is, a paradigm organized on the assumption that one person is matched to one machine, "freeing" the individual from the tyranny of computing's grey, hierarchical past. ${ }^{4}$ Roughly a decade passed before law and public policy began to really absorb the implications of the paradigm, particularly with regard to the acceptable "use" of that device. If computing "freed" the individual, what were the limits of that freedom, and where did those limits come from? Intellectual property law offers an example. In copyright law, what constitutes an infringing "reproduction" of a copyrighted computer program? Computer Associates International v. Altai, Inc., ${ }^{5}$ which set the standard for nonliteral reproduction, was decided in 1992. MAI Systems Corp. v. Peak Computer, Inc., ${ }^{6}$ which held that a RAM copy of a program was sufficiently "fixed" to be infringing, and Sega Enterprises $v$. Accolade, Inc., ${ }^{7}$ which established the legitimacy of reverse engineering for producing interoperable computer programs, were both decided in 1993.

of Workplace Safety, 57 Admin. L. REv. 1071 (2005); see also Orly Lobel, The Renew Deal: The Fall of Regulation and the Rise of Governance in Contemporary Legal Thought, 89 MINN. L. REV. 342 (2004).

2. Cf. Yochai Benkler, The Wealth of Networks: How Social Production TRANSFORMS MARKETS AND FREEDOM (forthcoming 2006) (framing the power of the networked information economy in terms of the enhanced capabilities of individuals).

3. Recall that the term "computer" was invented to characterize people, not machines. "Computers" were individuals, often women, who worked in teams to operate mainframe computers, and before the development of machines for computation, "computers" were people who computed, that is, who calculated or reckoned. See Paul E. Ceruzzi, A History OF MODERN COMPUTING 1 (1998)

4. Apple Computer memorably captured this sense of liberation in its famous "1984" television commercial, broadcast during the 1984 Super Bowl, which featured a lone athlete throwing an enormous hammer and exploding a screen image of a fictional "Big Brother."

5. 982 F.2d 693 (2d Cir. 1992).

6. 991 F.2d 511 (9th Cir. 1993).

7. 977 F.2d 1510 (9th Cir. 1993). 
Lotus Development Corp. v. Borland International, ${ }^{8}$ analyzing the copyrightability of program interfaces, was decided in 1995, and ProCD, Inc., v. Zeidenberg, ${ }^{9}$ the first case to give unequivocal endorsement to a shrinkwrap license for prepackaged computer software for the PC, was released in 1996. By the mid-1990s, in short, we could see the basic contours of an intellectual property jurisprudence of the "personal" computer.

At just about this time, that is, the mid-1990s, the Internet began to emerge as broad technological phenomenon. Law and policy analysis turned to the Internet, but it largely borrowed the individualistic policy framework that was emerging from the personal computing era. The mid- and late 1990s witnessed the introduction of compelling theoretical paradigms that still govern much of how we think about "cyberspace" law and policy. As before, the questions concerned freedom and sovereignty, and specifically how to conceptualize the relationship of the individual not to the individual machine, but to the potentially coercive computer network. Larry Lessig focused on the physical "architecture" of computer networks as a complement to the "architecture" of formal law, arguing that the former might be designed to influence individual behavior in ways that may be inconsistent with formal, legal norms. ${ }^{10}$ Lessig was both optimistic and pessimistic about the possibilities for technological regulation supplanting traditional law. Joel Reidenberg, writing around the same time, argued not that technology tells us something about the limits of law, but that law tells us something about the limits of technology. ${ }^{11}$ Reidenberg's point was that values encoded in formal law should not be lightly dismissed in the face of technological evolution. Despite the power of computer networks in transnational contexts, it should be possible to implement those values in new technical contexts, using the very malleability of computer technology that prompted Lessig's concern.

The recent salience of "social software" (a term that I discuss in the next Part) suggests that the Lessig/Reidenberg model, exploring the relationship between the individual and the technological sovereign, needs to be supplemented. In this first decade of the twenty-first century, we appear to be

8. 49 F.3d 807 (1st Cir. 1995); see also Apple Computer, Inc. v. Microsoft Corp., 35 F.3d 1435 (9th Cir. 1994) (rejecting copyright claims against Microsoft for infringement of alleged copyright in desktop metaphor and icons).

9. 86 F.3d 1447 (7th Cir. 1996).

10. See Lawrence Lessig, Code and Other Laws of Cyberspace 1-8, 30-42 (1999); Lawrence Lessig, The Law of the Horse: What Cyberlaw Might Teach, 113 Harv. L. Rev. 501, 506 (1999). That the underlying concern is the relationship between the individual and the sovereign state is even clearer in James Boyle, Foucault in Cyberspace: Surveillance, Sovereignty, and Hardwired Censors, 66 U. CIN. L. REV. 177, 177-78 (1997).

11. See Joel R. Reidenberg, Lex Informatica: The Formulation of Information Policy Rules Through Technology, 76 TEX. L. REV. 553, 554-55 (1998). 
in the early stages of the development of a new model of computing, one that explicitly recalls the origins of computing as a social discipline. Computer users are using technology collaboratively, explicitly, and in a multiplicity of ways that we can see for the first time. ${ }^{12}$ Contemporary computing is restoring the visibility of social patterns inherent in computer usage. It facilitates the creation and maintenance of informal, dynamic groups of people. As a result, not only do we need to assess the regulatory significance of these technologies, but we also face new challenges in appreciating the relationship between the law and groups themselves.

Groups are not new to the law, and technology developments aside, this Essay is more a reminder that we should be attentive to the potential significance of the informal group rather than a discovery of a novel phenomenon. $^{13}$ Law has long been happy to recognize groups and their benefits, so long as they are suitably formal. The paradigmatic private group is the firm, recognized legally as the corporation. The paradigmatic public group is the city. There are groups of other sorts-other business organizations, unincorporated associations, churches, clubs, and families-all of which sometimes call for specialized recognition and regulation in law. "Group" identity, however, is almost always a matter of form. Corporate status is granted by the state upon compliance with the corporations code. In law, a family begins with a marriage. Law channels social organization into prescribed forms, fictionalizing the entity for regulatory purposes. Absent the

12. Susan Crawford expresses the point as a supplement to the "layers" framework for conceptualizing the Internet: "Arguably, yet another layer is now evolving that facilitates the formation of complex social groups based on exchanges of bits and effective use of the metainformation that is generated by these exchanges," a layer that might be called the new "social protocol" layer of the Internet that lies on top of the "application layer" that is at the top of the current network hierarchy. Susan P. Crawford, Shortness of Vision: Regulatory Ambition in the Digital Age, 74 Fordham L. REv. 695, 699 n.12 (2005). Beth Noveck focuses on the visual dimension of the phenomenon: "[T]echnology is evolving to be more social and visual and therefore conducive to collective action by providing the means for collective visualization." Beth Simone Noveck, A Democracy of Groups, 10 First Monday, No. 11 (Nov. 7, 2005), http://www.firstmonday.org/issues/issue10_11/noveck/index.html; see also David R. Johnson, How Online Games May Change the Law and Legally Significant Institutions, 49 N.Y.L. SCH. L. REV. 51 (2004-2005).

13. Informal groups have begun to appear elsewhere in legal scholarship, beyond their traditional place in theories of social norms and interest groups. See Robert B. Ahdieh, The Role of Groups in Norm Transformation: A Dramatic Sketch, In Three Parts, 6 CHI. J. INT'L L. 231, 232 (2005) (discussing "clearly defined groups of market participants-committees, task forces, and the like-both in social ordering generally and in the adoption and evolution of norms"); Eduardo M. Peñalver, Property as Entrance, 91 VA. L. REV. 1889, 1892 (2005) (arguing that "property actually serves to facilitate 'entrance' into community by tying individuals into social groups"); see also infra notes 45-52 and accompanying text. 
prescribed form, law looks to the individual. Informal social structures are messy and dynamic; formal legal structures are relatively neat, and static. Part of my argument here is that something is lost in the translation. There may be good which comes from informal groups, good that which may be lost when group activity is channeled into typical legal forms.

From the technology side, then, the questions no longer consist only of the implicitly individualistic "What does technology tell us about how law regulates?," "What does law tells us about how technology regulates?," and the comparably pragmatic, "How do we get individuals to do what we want and to stop what we don't?" There is a new question, which is this: "What should the combination of technology and law tell us about what is, and should be, regulated?" It seems to me that computing technology is bringing informal groups to the fore.

The balance of this Essay proceeds as follows. Part I briefly describes some of these newer technologies. Part II points out some provocative theory and research-some within law and some without-that suggests that recognizing informal groups may serve the law well for reasons and in contexts that have little to do with technology. Part III illustrates how the approaches described in Part II are already implicitly recognized in the law, at least in part. As an example, this Part suggests that some difficult contemporary legal issues surrounding computer technology may be best understood as problems of trying to identify informal groups and their patterns of social behavior, rather than as problems of regulating individual behavior. This Part also suggests some ways in which the law might try to regulate group formation by regulating ways to heighten, or lessen, group salience.

\section{Social Software and Group Salience}

I use the term "social software" somewhat loosely, certainly more loosely than the term and its cousins-"social computing," "social technologies," and "social media"-are used by technologists themselves. ${ }^{14}$

14. For example, corporate research groups on the topic use a number of different names. Microsoft, IBM, and FX Palo Alto Labs each hosts a "Social Computing" group. See Social Computing Group Home, http://research.microsoft.com/scg/ (last visited May 18, 2005); IBM Research: Social Computing Group, http://www.research.ibm.com/SocialComputing/ (last visited May 18, 2005); FXPAL - Social Computing, http://www.fxpal.com/?p=socialComputing (last visited May 18, 2005). The University of California Berkeley hosts a "Social Technologies" research group. See Social Technologies Group, http://www.sims.berkeley.edu/ research/projects/socialtech/ (last visited May 18, 2005). The best known of the many weblogs dedicated to the subject is Many to Many which describes its subject matter as social software. See Corante: Many-to-Many, http://many.corante.com (last visited May 18, 2005). Some researchers identify their field as "sociable computing" or "sociable media." See Sociable 
Technologists often use "social software" specifically to describe a class of computer programs, environments, tools, and protocols that are designed to enhance individual productivity or sociability in group settings on the Internet or other computer networks. I borrow the term in order to capture two more general phenomena. The first is the fact that some computer programs are designed to enable the interaction of individuals with one another, particularly as parts of both pre-existing and new groups, small and large. The key feature here is the dynamism of group affiliation. Informal groups are stable, but not static. Individuals come and go, altering the group in some sense and possibly, though not necessarily, changing it to such an extent that the group dissolves, or becomes a different group.

The second, which is related to the first, is the fact that many of these technologies allow us to "see" the contours of both the interaction and the group itself. "Seeing" has a couple of dimensions. In part it means that the dynamic character of the group is visible. In part it means that the stability or permanence of the group is visible. "Seeing" the contours of the interaction and of the group means, in other words, that these systems typically are not simply about creating and exchanging data, whether that data is "information" or creative "content" or something else. They are about creating and exchanging data connected to social identity. There is a relative permanence to these relationships; the data "belongs" to someone, in an intuitive if not formal or legal sense, and that data identity is related to other identities in the system in ways that are generally persistent over time.

Social software, in short, is technology that embodies evolving social patterns-meeting, communicating, and processing and sharing information across communities, groups, and other collectives. ${ }^{15}$ It heightens the salience of informal, stable online groups. In many cases, user-interface design and

Media Group-MIT Media Lab, http://smg.media.mit.edu/ (last visited May 20, 2005) (exploring questions of identity and society in the context of computer networks). "Social media," which is used (among other places) in the title of American University's Center for Social Media, embraces uses of "traditional" media, including television and film, for collaborative and civic purposes.

15. On the relationship between sociocultural behavior, and stable patterns of information distribution and use, see BENEDICT ANDERSON, IMAGINED COMMUNITIES: REFLECTIONS ON THE ORIGIN AND SPREAD OF NATIONALISM 44-45 (1991) (noting that print technology, as standardized, fixed, and authoritative, enables the rise of "imagined" or "virtual" communities, as compared to "real" communities); DAVID S. KAUfER \& KATHLEEN M. CARLEY, Communication at a Distance: The Influence of Print on Sociocultural Organization AND CHANGE 205-50 (1993) (The authors describe a "constructuralist" model of sociocognitive behavior, link individual agency with dynamic properties of groups, and argue that the shape and pace of the information exchange is influenced by the character of the communication technology used. Print, in particular, affects the diffusion, stability, and consensus-related dimensions of information.). 
other user-accessible features of these technologies enable individuals literally to observe the actions of others using the same technology, synchronously or asynchronously. ${ }^{16}$ (Users of the technology may see those relationships, or observers of the use may do so, and in some cases both do.) In others, the salience of the group itself is indirect but is apparent via artifacts that reify the group, wholly or partially. The sum of it is that "social software" supports the formation of dynamic social relationships customized by the individuals who create and perpetuate them, and it makes social groups visible via their activity in, on, and using a computer network. ${ }^{17}$ Some examples, focused particularly on technologies that have been the focus of debates about law and public policy, make this description more concrete:

Peer-to-Peer Technologies. Peer-to-peer or "P2P" technologies came to popular attention via litigation over the original Napster music-sharing

16. The Science, Technology \& Society research community would note that social software is not itself a class of technologies; social software is about particular socio-technical domains. That argument is certainly consistent with mine. Here, I simplify in order to make the initial discussion clearer.

17. On the importance of "weak ties" in social networks, see Mark Granovetter, The Strength of Weak Ties: A Network Theory Revisited, 1 Soc. THEORY 201 (1983); Gabriel Weimann, The Strength of Weak Conversational Ties in the Flow of Information and Influence, 5 SOC. NETWORKS 245 (1983). On the benefits of salience for group activity, and how salience can be enhanced via technical design, see, for example, Thomas Erickson \& Wendy A. Kellogg, Social Translucence: An Approach to Designing Systems that Support Social Processes, in 7 ACM TRANSACTIONS ON COMPUTER-HUMAN INTERACTION 59 (2000) (describing digital systems that support coherent but fluid group behavior by making participants and their activities visible to one another; such systems are characterized by visibility, awareness, and accountability, which enable people to draw on their social experience and expertise to structure their interactions). Salience and visibility enhance understanding. "All communication between the readers of an image and the makers of an image must now take place on a two-dimensional surface. Escaping this flatland is the essential task of envisioning information-for all the interesting worlds (physical, biological, imaginary, human) that we seek to understand are inevitably and happily multivariate in nature." EDWARD R. TUFTE, ENVISIONING INFORMATION 12 (1990) (emphasis in original). To the extent that a sense of connectedness reinforces connections themselves, salience and visibility may enhance the formation and persistence of groups. See Brian S. Butler, Membership Size, Communication Activity, and Sustainability: A Resource-Based Model of Online Social Structures, 12 INFO. SYS. RES. 346 (2001) (arguing that salience may enhance the perceived benefits of groups, including opportunities for affiliation or companionship, opportunities to influence people, social support, access to information, the ability to disseminate ideas rapidly, and support for collective action). Social networking researchers note that people vary widely in their ability to intuit the existence, scale, and functioning of social networks. See Daniele Bondonio, Predictors of Accuracy in Perceiving Informal Social Networks, 20 Soc. NeTwORKS 301 (1998); Ece Kumbasar et al., Systematic Biases in Social Perception, 100 AM. J. Soc. 477 (1994). 
service, ${ }^{18}$ and its successors, including Aimster ${ }^{19}$ and Grokster. ${ }^{20}$ These programs and their $\mathrm{P} 2 \mathrm{P}$ cousins share a basic network architecture that makes each client computer a potential network peer, able to upload content to other client computers as well as to download content from them. Users on a P2P network can search inventories of material on other users' computers, and can deliver and retrieve material directly to and from other users, without necessarily relying on access to a central data server. Whether authorized or unauthorized, a peer-to-peer network creates and supports a form of group interaction using the Internet that is distinguishable from what has become the conventional server-client form of distribution of digital content. P2P networks need not be driven by interests in music or movies, a point that is illustrated by the success of the Groove Networks commercial P2P platform for office productivity. ${ }^{21}$

Open Source Software. "Open source" computer programs, sometimes known as "Free/Open Source Software" or F/OSS, are distinguished legally by their distribution under software license regimes that mandate user access to the source code of the programs. The licenses give users a power to modify and adapt programs that is otherwise all but forbidden, as a technological and legal matter, when programs are distributed only in object code format. In most instances, F/OSS licenses authorize users to redistribute their modifications so long as they do so using comparable "open source" licensing terms. I regard open source as a form of social software not merely because of the licensing regime that supports it, but because the license regime implements and confirms the notion that development of an "open source" program is meant to be a continuing, collaborative process distributed across time, space, and environment, rather than a "product" that emerges as a "thing" from an integrated firm. Echoing its social dimension, Yochai Benkler describes open source as a prime example of "[c]ommons-based peer production." 22

Weblogs. It is virtually impossible to define "weblog"; the term has become jargon for a collection of technologies and styles of posting material to websites that are formatted chronologically, like diaries. Blogs may be academic or intellectual; they may be political; they may be intensely personal. What makes blogs social is not their content, but the variety of

18. See A \& M Records, Inc. v. Napster, Inc., 239 F.3d 1004 (9th Cir. 2001).

19. See In re Aimster Copyright Litig., 334 F.3d 643 (7th Cir. 2003), cert. denied sub nom. Deep v. Recording Indus. Ass'n of Am., 540 U.S. 1107 (2004).

20. See Metro-Goldwyn-Mayer Studios, Inc. v. Grokster Ltd., 125 S. Ct. 2764 (2005).

21. See Groove Virtual Office, http://www.groove.net (last visited Feb. 14, 2005).

22. Yochai Benkler, Coase's Penguin, or Linux and the Nature of the Firm, 112 YALE L.J. 369, 375 (2002). 
technologies that exist to enable readers and writers to communicate with one another about their content. Blog content may be distributed to readers via "syndication" technology that reformats blog content and delivers it electronically to aggregators and news readers used by readers. Blog authors may post lists of links to other blogs, suggesting a constellation of blogs of possible interest to readers with certain interests. Bloggers may enable readers to post comments on blog posts. "Trackback" technology, which marks instances in which blogs discuss posts at other blogs, allows bloggers and readers alike to watch posters, readers, and other blogs respond to one another. Third-party services such as Technorati ${ }^{23}$ and Bloglines ${ }^{24}$ offer technological facilities to bloggers and readers that allow both to see the web of links that extends to and from a blog. The simplicity of blogging technologies has led not only to their rapid integration into the World Wide Web itself but to their combination with other computer networking developments: "Moblogging," for example, describes the integration of blog technology and mobile networking. Bloggers can post blog content, including sound, video, and still images, as well as text, from mobile devices.

Collaborative Authoring Technologies. Though weblog technologies enable groups of authors to post to single weblogs, two of the best-known forms of collaborative authoring technologies are wikis and slashdot. When implemented as a website, a wiki allows any visitor to post content, edit content, or delete content. The collaborative writing and editing process likewise extends to the structure of the material that resides on the wiki. (The term sometimes also refers to the computer program that supports this sort of forum. $)^{25}$ The most celebrated and robust implementation of a wiki is the Wikipedia, ${ }^{26}$ a sort of online encyclopedia that consists of content contributed to and edited by the user population itself. The quality of Wikipedia content appears to vary, depending on the depth and level of engagement of the relevant user population. This level of engagement is precisely what prompts characterization of the wiki idea as a form of social software, since the software creates usable output only to the extent that the output is sustained by a population of users that is willing to police the wiki. Slashdot ${ }^{27}$ is the best-known implementation of the Slash technology. ${ }^{28}$ While the content of

23. See Technorati: Home, http://www.technorati.com (last visited Feb. 14, 2005).

24. See Bloglines, http://www.bloglines.com (last visited Feb. 14, 2005).

25. See Front Page, http://c2.com/cgi/wiki (last visited Feb. 14, 2005).

26. See Wikipedia, http://www.wikipedia.org (last visited Feb. 14, 2005).

27. See Slashdot: News for Nerds, Stuff That Matters, http://www.slashdot.org (last visited Feb. 14, 2005).

28. See Slashcode: Slash Open Source Project, http://www.slashcode.com (last visited Feb. 14, 2005). 
the site is technology news, it is neither a weblog (as that term has come to be used) or a wiki, but it shares some attributes of both. Slashdot is a Web-based forum for news and information about computer technology. Like a blog, content to the slashdot.org website is posted sequentially and chronologically. Like a wiki, anyone can post new material and can comment on existing material. Unlike either, however, the Slash technology includes a "polling" feature that enables regular visitors to the site effectively to "rate" postings by other visitors, and effectively to drive low-rated postings, and posters, from the site. A small group of moderators retains editorial discretion over the site as a whole, giving the entire setup the feel of a managed community.

Social Networking Software. The term "social networking software" encompasses an ever-expanding list of Web-based computer technologies, many oriented to one or more commercial markets, that are designed to help individuals and businesses share information about one another, and possibly to meet one another and develop and nurture relationships. The relationships may remain entirely virtual and "informational," or they may transition into "real space." They may remain one-to-one, or they may be part of community or group building. They may be based on finding others with shared political, intellectual, or social interests. They may be little more than online dating services. Or they may offer ways for companies and individuals in business to develop business partners or customer or supply networks. ${ }^{29}$

Virtual Worlds. Among the earliest forms of social software were multiplayer online games, sometimes known as virtual reality systems or virtual worlds. Some of these are now so large and complex that they are referred to by the acronym MMORPG (Massive Multi-player Online Role Playing Games). More broadly and generally, they may be referred to by the more humble acronym, MMOG (Massive Multi-player Online Games), to encompass online virtual worlds that do not involve role playing by participants. Earlier versions, still available in some corners of the Internet, are related spaces called MUDs (Multi-User Dungeons, or Multi-User Domains, which are text-based multi-player environments) and MOOs (MUD Object-Oriented, or multi-player environments that combine text-based

29. By listing examples here, I run a clear risk regarding both timeliness and hipness, or lack of both. Some of the better known personal social networking sites include Meetup, Inc., http://www.meetup.com; Friendster, http://www.friendster.com; Orkut, https://www.orkut.com; MySpace.com, http://www.myspace.com; Tribe Networks, http://www.tribe.net; LinkedIn, http://www.linkedin.com; craigslist, http://www.craigslist.org; and Facebook, http://www.facebook.com (all last visited May 20, 2005). Social networking sites oriented to commercial sales and marketing professionals include Ryze, http://www.ryze.com; Spoke, http://www.spoke.com; and Socialtext, http://www.socialtext.com (all last visited May 20, 2005). 
interaction with multimedia sound and visual features). Using any of these technologies, individuals $\log$ in to the game environment and adopt a "role," known to gamers as an "avatar," 30 either themselves or an inhabited character, in which to engage other players. The point may be to build and inhabit a community, or to accumulate wealth, or to do any of an enormous variety of things, many of which track "real life" activities. To an increasing extent, MMORPGs are developed and managed by entertainment companies that develop and distribute the software that individuals use to access the game environment, and that host and manage the computer servers that run the software that creates that environment.

Social Tagging Technologies. An intuitive inventory of computer software that supports social interactions may not include online auctioneers and booksellers, but eBay and Amazon.com have succeeded as electronic commerce ventures in part precisely because of social mechanisms built into their businesses. eBay offers its users the ability to deliver online ratings to buyers and sellers, allowing all who use eBay's facilities the ability to judge the trustworthiness of their potential business partners. ${ }^{31}$ Amazon.com does something similar by offering anyone who visits its site the ability to post reviews of its products. Features of eBay and Amazon.com may be characterized as species of social tagging systems, in which members of the group use group tools to label, rate, or otherwise give meaning to actions by other individuals or entities in the group. ${ }^{32}$ From a technical standpoint, another example is the Semantic Web, ${ }^{33}$ an effort to develop a means to "code" content on websites so that computers can interpret the meaning of that content, rather than merely render a display of the underlying HTML coding. This, of course, is a sort of machine sociability, but it reflects the sensibility that there is more to a computer network than an individual's interaction with a computer. A more provocative example is the Microsoft Research project

30. The legal implications of the embodied self have received a lot of recent attention. See, e.g., Jack M. Balkin, Law and Liberty in Virtual Worlds, 49 N.Y.L. SCH. L. REV. 63, 68-71 (2004-2005) (exploring the limits of the "right to design" and the "right to play"); Susan P. Crawford, Who's in Charge of Who I Am?: Identity and Law Online, 49 N.Y.L. SCH. L. REV. 211, 213-15 (2004-2005) (describing the online identities of avatars as an emergent, group process); David R. Johnson, How Online Games May Change the Law and Legally Significant Institutions, 49 N.Y.L. SCH. L. REV. 51, 52 (2004-2005) (describing the variety and flexibility of avatar roles); F. Gregory Lastowka \& Dan Hunter, The Laws of the Virtual Worlds, 92 CAL. L. REV. 1, 10-11 (2004) (describing the intersections between real and virtual avatar presences).

31. See Feedback Forum, http://pages.ebay.com/services/forum/feedback.html (last visited Feb. 14, 2005).

32. "Social tagging" websites include del.icio.us, http://del.icio.us, and flikr.com, http://flikr.com (both last visited May 20, 2005).

33. See Tim Berners-Lee et al., The Semantic Web, 284 ScI. Am. 34 (2001). 
named Aura, ${ }^{34}$ which enables owners of mobile digital network devices (such as PDAs) to "annotate" everyday objects by scanning their UPC bar codes and entering new data about the objects into a distinct database. Anyone with a UPC bar-code scanner may scan the object and access the contents of the database. As with the wiki concept, anyone may upload new information about that object; the data is contributed to what amounts to a wikipedia for things. The object "becomes" its construction via engagement by users and consumers, rather than existing only as the UPC value declared by its manufacturer. And information about the thing becomes potentially widely distributed, rather than being concentrated in the thing itself.

My inventory does not exhaust the possibilities. Grid computing, e-mail lists, Internet Relay Chat (IRC), podcasting, instant messaging technologies, and even Google's PageRank algorithm each could be characterized similarly as social software, that is, as a tool for engaging in and tracking individual contributions to collaborative, collective, or group activity, through salient or visible features of the technology. The next question is whether, and why, law and policy should care about these things.

\section{The Virtues of Informal Groups}

I do not want to overstate the novelty of this project. Sociologists and other social scientists have been studying informal groups for a century, ${ }^{35}$ and the dynamics of informal "social networks" have themselves been the objects of scholarly attention for nearly that long. ${ }^{36}$ All of the Internet is social software, in an abstract sense. From the beginning, informal groups have been the very point of computer networking. J.C.R. Licklider, known by some as

34. See Marc A. Smith et al., Object AURAs: A Mobile Retail and Product Annotation System, in ProceEdings of THE 5TH ACM ConferenCE ON EleCtroniC CoMmerce 240, 24041 (2004); MSR AURA Portal-Annotate the Planet!, http://aura.research.microsoft.com (last visited Feb. 14, 2005).

35. A small sampling of this literature includes Robert M. AXELrod, The Evolution of Cooperation (1984); Manuel Castells, The Rise of the Network Society: The Information Age: Economy, Society, And Culture, Vol. 1 (2d ed. 2000); Erving Goffman, The Presentation of Self in Everyday Life (1959); Edward T. Hall, The Hidden Dimension (1966); Elinor Ostrom, Governing the Commons: The Evolution of Institutions for Collective Action (1990); Duncan J. WAtts, Six Degrees: The Silence of a Connected Age (2003); William H. Whyte, City: Rediscovering the Center (1988); Samuel Bowles \& Herbert Gintis, Social Capital and Community Governance, 112 Econ. J. F419 (2002).

36. See, e.g., J. L. Moreno, Who Shall Survive? A New Approach to the Problem OF HUMAN INTERRELATIONS (1934). An interesting intellectual history of the field is LiNTON C. Freeman, The Development of Social Network Analysis : A Study in the Sociology OF SCIENCE (2004). 
the father of the Internet, wrote that computer networking had the potential to make visible models of cooperative behavior that made human communication possible. $^{37}$

What is different now, then, about the diverse cluster of computing applications that I inventoried in the last Part? At one level, the answer, I think, is nothing. Informal groups are informal groups, whether they are online, or offline, or both. Sociologists and other social scientists do know quite a bit about groups: what constitutes a group, how and why a group forms, and how a group operates. ${ }^{38}$ There is a long and deep tradition of respecting informal groups in American society and polity, ${ }^{39}$ and there is little reason to think that Internet-enabled groups are any more or less

37. See J.C.R. Licklider \& Robert W. Taylor, The Computer as a Communication Device, SCI. \& TECH., Apr. 1968, at 76, 77-78, available at http://gatekeeper.dec.com/ pub/DEC/SRC/publications/taylor/licklider-taylor.pdf:

When people communicate face to face, they externalize their models so they can be sure they are talking about the same thing. Even such a simple externalized model as a flow diagram or an outline-because it can be seen by all the communicatorsserves as a focus for discussion. It changes the nature of communication: When communicators have no such common framework, they merely make speeches $a t$ each other; but when they have a manipulable model before them, they utter a few words, point, sketch, nod, or object.

The dynamics of such communication are so model-centered as to suggest an important conclusion: Perhaps the reason present-day two-way telecommunication falls so far short of face-to-face communication is simply that it fails to provide facilities for externalizing models.

This model of the network fits hand-in-glove with Licklider's earlier concept of "man-computer symbiosis": "The hope is that, in not too many years, human brains and computing machines will be coupled together very tightly, and that the resulting partnership will think as no human brain has ever thought and process data in a way not approached by the information-handling machines we know today." J.C.R. Licklider, Man-Computer Symbiosis, HFE-1 IRE Transactions Hum. Factors Elecs. 4, 5 (1960).

38. The sorts of questions that sociologists would ask about social software might include: How do these groups get formed, and how do they decay? What is the value in computing-does it lie in the creation, in the distribution, in the exchange, and/or in sociability itself? How do these tools reflect and change how we interact with other people? How do people create value in a group? How do members present themselves to each other and to outsiders? Are these really "groups" in a sociological sense, or are they communities, or associations? What are the boundaries of the group, and what are its power dynamics? Why do people behave in certain ways in groups? Cooperate? Defect? How do they create trust, or authenticity, or betray it? How and why do they manage the resources of the group?

39. The tradition that links social capital and associational activity to political and economic well-being runs from Alexis de Tocqueville through Robert Putnam. See RoBERT D. Putnam, Bowling Alone: The Collapse and Revival of American Community (2000); Robert D. Putnam, Making Democracy Work: Civic Traditions in Modern Italy (1993). 
comprehensible, or socially valuable, than groups that are not enabled by the Internet.

The law, on the other hand, has long been skeptical of informal groups. ${ }^{40}$ The legal system does not know much about how to interrogate them, and despite a lot of sustained effort, has never really succeeded in reconciling the notion of the group with the authority of the state. ${ }^{41}$ Part of the skepticism may be based on held-over Enlightenment philosophy; part of it may be suspicion of entities that are difficult to define with precision. ${ }^{42}$ The law regulates individuals, or the law channels group behavior into a regulable form, i.e., the firm. The power of this dualism is evident, for example, in Yochai Benkler's recent article exploring social sharing as a modality of economic production. ${ }^{43}$ Benkler's work consists of a thorough investigation of the characteristics of the goods that lend themselves to production via a social sharing model, using open source computer software as his principal example. The oppositions that he sets up are social sharing versus markets (i.e., individual exchange), and social sharing versus hierarchies (i.e., firms). Social sharing appears to be a function of informal groups mediated by certain material conditions, yet Benkler is mostly unconcerned with the dynamics of the groups themselves. He traces his analysis to the bedrock assumption that social sharing may be a superior method of supporting individual agency in the production process. ${ }^{44}$ The question is the circumstances under which that is true.

Yet if popular writing is any guide, then there is something to the sense that Internet technologies make forming and preserving informal groups online somewhat easier than doing so offline. Howard Rheingold followed his The Virtual Community in $2000^{45}$ with Smart Mobs in 2002. ${ }^{46}$ Lior Strahilevitz is

40. That skepticism is most pronounced in conventional accounts of democratic processes, from Madison's effort to defend the Constitution as a mechanism for limiting faction, see The Federalist No. 10, to Cass Sunstein's recent skeptical analysis of the Internet, see generally CASS SunStein, Republic.com (2001). For a critical view of Sunstein's argument, and one more sympathetic to the role of groups generally and online in particular, see Dan Hunter, Philippic.com, 90 CAL. L. REV. 611 (2002).

41. See supra notes 10-11 (describing Lessig/Reidenberg models of cyberspace law). A useful synthesis of the struggle appears in Paul W. Kahn, Community in Contemporary Constitutional Theory, 99 YALE L.J. 1 (1989).

42. See Beth S. Noveck \& David R. Johnson, Society's Software, 74 FordHAM L. REV. 469, 472-73 (2005).

43. Yochai Benkler, Sharing Nicely: On Shareable Goods and the Emergence of Sharing as a Modality of Economic Production, 114 YALE L.J. 273 (2004).

44. See id. at $278 \&$ n.5.

45. See generally Howard Rheingold, The Virtual Community: Homesteading ON THE ElECTRONIC Frontier (2000).

46. See generally Howard Rheingold, Smart mobs: The Next Social Revolution 
working through applications of network theory to privacy and file-sharing, among other things; ${ }^{47}$ Dan Hunter and Greg Lastowka are pursuing the economic implications of empowering groups of individuals in online networks; ${ }^{48}$ and Beth Noveck is developing a theory of groups as democratic actors. ${ }^{49}$ The sense that we should give informal groups another look has carried over into analyses of offline behavior as well. On the popular side, James Surowiecki published The Wisdom of Crowds in $2004,{ }^{50}$ distilling economic and social networking research into the simple thesis that large, diverse, decentralized, and loosely affiliated groups of people can be effective at solving problems and finding answers. Philip Ball's Critical Mass recently presented a comparable argument by using principles of physical science to analyze social phenomena. $^{51}$ Legal scholars are reexamining group sensibilities in offline contexts. ${ }^{52}$

I suspect that a couple of things are going on. One is obviously technological. Social software is taking the promise that Licklider saw-a promise based, of course, on our deep-seated associational traditions-and is realizing it in ways both real and visible. A second is the confluence of that technological development with literature in sociology and economics. Economists, at least since Hayek, have understood the value of markets-i.e., large groups of people-in aggregating diverse, distributed information. Sociologists have long sensed the existence of informal groups but have had

(2002) (Rheingold argues that new mobile electronic technologies enable large groups of people to communicate quickly and coordinate their activities.).

47. See, e.g., Lior Jacob Strahilevitz, Charismatic Code, Social Norms, and the Emergence of Cooperation on the File-Swapping Networks, 89 VA. L. REV. 505 (2003) (article discussing file-swapping hybrids).

48. See, e.g., Dan Hunter \& F. Gregory Lastowka, Amateur-to-Amateur, 46 WM. \& MARY L. REV. 951 (2004) (article discussing this issue).

49. See Noveck, supra note 12. Other examples of recent legal scholarship that might be characterized as investigations of group agency include: Crawford, supra note 12; Jonathan Zittrain, The Generative Internet, 119 HARV. L. REV. (forthcoming May 2006) (on file with author); Philip J. Weiser, The Internet, Innovation, and Intellectual Property Policy, 103 COLUM. L. REV. 534 (2003).

50. See James Surowiecki, The Wisdom of Crowds: Why the Many are Smarter than the FeW and How Collective Wisdom Shapes Business, ECONOMIES, Societies, AND NATIONS (2004).

51. See Philip Ball, Critical Mass: How One Thing Leads to Another (2004).

52. See David McGowan, From Social Friction to Social Meaning: What Expressive Uses of Code Tell Us About Free Speech, 64 Oніо ST. L.J. 1515, 1516 (2003); Miranda Oshige McGowan, From Outlaws to Ingroup: Romer, Lawrence, and the Inevitable Normativity of Group Recognition, 88 MinN. L. REV. 1312, 1312-15 (2004); Robert K. Vischer, The Good, the Bad and the Ugly: Rethinking the Value of Associations, 79 Notre DAME L. REV. 949, 949-53 (2004). 
difficulty (or have not been concerned with) articulating their normative value, aside from the purposive goals of some of them. As those groups become more salient, we see the urge to explore whether informal groups could be good for something, even if we do not know as much as we would like about how they work. Something more important than block parties, more specific than pricing, and more tangible than civic republicanism. ${ }^{53}$ Benkler's account of "social sharing" fits this premise, even if his account of open source software production as an example of "social sharing" is built around the characteristics of inputs and outputs, rather than around the characteristics of the open source programmer community. He uses other examples to round out the model, but neither of them-distributed computing, nor "casual" carpooling traditions in the San Francisco Bay Area and Northern Virginia-can be explained fully without an account of the groups that support them. ${ }^{54}$ The Internet preceded SETI@home; the interstate highway system preceded casual carpooling. If these three phenomena are all truly examples

53. One outstanding example of how information policy might build on salient features of institutional settings is John Seely Brown \& Paul Duguid, The Social Life of INFORMATION 207-41 (2000), which discusses the issue in depth.

54. On the social dimensions of P2P systems, see Eytan Adar \& Bernardo A. Huberman, Free Riding on Gnutella, 5 FIRST Monday, No. 10 (Oct. 2, 2000), http:// www.firstmonday.dk/issues/issue5_10/adar/index.html. Hunter and Lastowka offer an economic account of P2P file-sharing that focuses on group dynamics first. See Hunter \& Lastowka, supra note 48, at 951. As for casual carpooling, the "goods"-based account predicts that the system would arise concurrently with the material conditions that define it: carpool lanes on the highway and spare seats in the cars. But casual carpooling in the Bay Area did not arise for more than ten years after carpool lanes were installed on the San Francisco-Oakland Bay Bridge. Toll reductions for carpools were implemented in 1971. See The San Francisco-Oakland Bay Bridge, http://www.dot.ca.gov/hq/esc/tollbridge/SFOBB/ Sfobbfacts.html (last visited May 20,2005). Casual carpooling has been in existence only since the late 1980s. See What are Casual Carpools?, http://www.ridenow.org/carpool/what.htm (last visited May 20, 2005) (describing the system as having been in existence "for more than 20 years"). It really took off only as groups of carpoolers and drivers were able to literally see one another. For years, casual carpooling depended entirely on word of mouth and, more broadly and deeply, on the observations of people who drove alone into San Francisco, bypassing the lines of waiting carpoolers and then being passed by them while waiting to pay the tolls. The local public transit system initially objected to this use of "its" sidewalk space at first, but the carpooling system grew popular enough that cities installed signs adjacent to bus stops, directing casual carpoolers to stand in certain places. Newspaper publishers added sidewalk newspaper boxes. Sometimes lines of people would wait for cars; sometimes lines of cars would wait for people. The point is that casual carpooling did not gain a foothold as an economic system of empty seats; it gained a foothold as an informal dynamic group based on visible material conditions and a set of informal norms about locations and driver/rider behavior. The visibility of the system helped create a virtuous circle. I was a casual carpool system user for several years in the San Francisco Bay Area and participated in the early development of this "sharing" mechanism. 
of "social sharing," then it may be sounder to characterize their positive welfare effects as by-products of groups. If informal groups are valuable, even-or especially-if that is true for reasons that we have difficulty articulating, then the law should pay attention. The salience of informal groups, particularly in technological context, means that the law should revisit its long standing reluctance to acknowledge them as a regulatory matter.

The remainder of this Part describes, briefly, three examples of what might be called "middle range" normative accounts of informal groups, accounts that are broad enough to be interesting and potentially useful as policy matters, but not so broad that they swallow law or policy as an entire domain.

\section{A. Lawmaking Groups}

The logical place to start considering the value of groups is democratic theory and the argument for pluralism in law and politics. Beth Noveck's recent work argues precisely this point, that "technology is revolutionizing our capacity for purposive collective action with geographically remote actors," ${ }^{55}$ and that informal collectives relying on social technologies can take their rightful place as legitimate institutions as such in political theory, capable of being recognized as more than simply mechanisms for transmitting individual interests. ${ }^{56}$ Somewhat similarly, Michael Froomkin has argued that, by virtue of particular technological and social conditions, certain informal groups involved in setting technical standards for the Internet may satisfy the rigorous conditions required to establish a Habermasian discourse and thereby demonstrate the legitimacy of their governing. ${ }^{57}$

An even richer and more provocative suggestion regarding the role of groups in law comes from the work of Robert Cover. Cover argued that the very meaning of law arises naturally from collectives of people, what Cover

55. Noveck, supra note 12.

56. For contrast, Noveck cites the conventional accounts of individual and collective action provided by C. Fred Alford, Group Psychology And Political TheOry (1994) and Mancur Olson, The Logic of Collective Action: Public Goods and the Theory of GROUPS (1965); see also Noveck \& Johnson, supra note 42, at 469-70 (describing significance of groups in First Amendment context).

57. See A. Michael Froomkin, Habermas@Discourse.Net: Toward a Critical Theory of Cyberspace, 116 HARV. L. REV. 749, 752 (2003). In a recent paper, Froomkin makes a more concrete argument about the need for government to encourage informal, self-governing groups and institutions. See A. Michael Froomkin, Building the Bottom Up From the Top Down (Working Paper 2006) (on file with author). The paper offers a series of eight steps that the government could take to promote formation of groups. 
called interpretive communities, rather than being developed and imposed via a sovereign. ${ }^{58}$ Each interpretive community constitutes a distinct nomos, or normative universe, "an integrated world of obligation and reality from which the rest of the world is perceived." 59 An interpretive community is defined by its narrative: "Every prescription is insistent in its demand to be located in discourse-to be supplied with history and destiny, beginning and end, explanation and purpose. And every narrative is insistent in its demand for its prescriptive point, its moral." ${ }^{60}$ Amid a multiplicity of interpretive communities, the role of the state is purely coercive, by asserting and then enforcing a superior right to interpretation.

The optimistic view of Cover's argument, which is what I borrow here, relies on his conclusion: "Legal meaning is a challenging enrichment of social life, a potential restraint on arbitrary power and violence. We ought to stop circumscribing the nomos; we ought to invite new worlds." ${ }^{\prime 61}$ In concrete terms, though Cover framed his argument primarily in terms of the narratives that define interpretive communities, he invited law to recognize the legitimacy of the lawmaking function of informal groups. ${ }^{62}$

Not all collectives generate the meanings that Cover suggested be recognized. It is not that there are good groups and bad groups. Groups exist, or do not. Interpretive communities, he proposed, share three characteristics: "[(1)] a common body of precept and narrative, (2) a common and personal way of being educated into this corpus, and (3) a sense of direction or growth that is constituted as the individual and his community work out the implications of their law." ${ }^{\prime 3}$

58. See Robert M. Cover, The Supreme Court, 1982 Term-Forward: Nomos and Narrative, 97 HARV. L. REV. 4 (1983).

59. Id. at 31 .

60. Id. at 5 .

61. Id. at 68 .

62. A recent effort to formalize Cover's theory calls these "nomic groups." See Franklin G. Snyder, Nomos, Narrative, and Adjudication: Toward a Jurisgenetic Theory of Law, 40 WM. \& MARY L. REV. 1623, 1625 (1999). Importantly, of course, Cover distinguished between groups sanctioned by the state and those that exist autonomously. More recent commentators have argued that Cover's work challenges us to explore connections between the state and groups, rather than to preserve distance between them. See Judith Resnik, Living Their Legal Commitments: Paideic Communities, Courts, and Robert Cover, 17 YALE J.L. \& Human. 17, 26 (2005) ("I read Cover as endlessly fascinated with the interactions between the state and paideic communities-and with the potential for such interactions themselves to be jurisgenerative moments.”).

63. Cover, supra note 58, at 12-13. Cover characterizes this as a "paideic" pattern of community formation, contrasting it with an "imperial" pattern of norms, objectively defined and subscribed to. 
Call these elements the narrative, the social structure, and the set of shared commitments among group members and between group members and the group which as a whole define the community. The group is dynamic; it learns, and it grows, with reference to both its content and its membership:

Law as Torah is pedagogic. It requires both the discipline of study and the projection of understanding onto the future that is interpretation. Obedience is correlative to understanding. Discourse is initiatory, celebratory, expressive, and performative, rather than critical and analytic. Interpersonal commitments are characterized by reciprocal acknowledgment, the recognition that individuals have particular needs and strong obligations to render person-specific responses. ${ }^{64}$

In the right time, then, and given the right conditions, informal groups of a variety of sorts justify what Cover might have called "nomic" treatment. Less formally, the existence of an informal group might itself justify some heightened degree of deference to the internal normative commitments of that group. ${ }^{65}$ Note, of course, that the existence of "nomic" groups remains to be demonstrated, rather than assumed, and the conclusion that legal meaning both does and should grow out of these groups is controversial. But Cover's work offers an initial hook for thinking provocatively about what good groups might do.

\section{B. Cognitive Groups}

A second point of departure, though one that is no less provocative, is the work of some scholars of cognitive social science. The question here goes to learning and adaptability, and to innovation and creativity, which lie at the

64. Id. at 13 .

65. Some recent work on electronic commerce and intellectual property licensing suggests that the law take precisely this direction. See, e.g., Robert P. Merges, From Medieval Guilds to Open Source Software: Informal Norms, Appropriability Institutions, and Innovation (Working Paper 2004), available at http://ssrn.com/abstract=661543 (relying in part on the virtues of medieval business collectives); Michael J. Madison, Reconstructing the Software License, 35 LOY. U. CHI. L.J. 275, 338-39 (2003). My article points out that focusing on the social benefits of salience may be a point of entry for justifying the open source license as a legitimate governance mechanism. See generally Reidenberg, supra note 11 (article emphasizing the virtues of governance by private collectives, using examples from medieval business practice); Lisa Bernstein, Merchant Law in a Merchant Court: Rethinking the Code's Search for Immanent Business Norms, 144 U. PA. L. REV. 1765 (1996) (same). I draw out these examples because Cover's sensibility echoes a pre-Enlightenment social ethos that focuses on relationships among social groups of different sizes and types, rather than on the relationship between the state and the individual. See Snyder, supra note 62, at 1636-42 (summarizing work on Cover that emphasizes this aspect of his theory). Nomos and narrative, informal groups, and software licensing are thus more closely related than they might initially appear. 
heart of contemporary debates about patent and copyright policy and about free speech, innovation, and information policy generally.

The classic model of human cognitive processing is that of the individual mind, processing formal symbolic representations of the world. In most research on the cognitive dimensions of "creativity," for example, researchers focus on the attributes of the "creative" individual ${ }^{66}$ In recent years, however, an alternative model has begun to emerge, one that describes cognition, and the cognitive dimensions of learning and adaptation, in sociocultural terms. Cognition is a group activity, not purely an individual one.

Among the best-known pieces of research that illustrates the point is Edwin Hutchins's Cognition in the Wild ${ }^{67}$ Hutchins, an anthropologist at the University of California San Diego, set out to study how sailors navigate. He sailed with several American naval vessels, including two aircraft carriers and two amphibious ships, to observe how naval personnel handled their responsibilities on the navigation bridge of each one. One of the latter, the Palau, frames most of the data and analysis in his book.

Hutchins's core finding is that the problem-solving (i.e., cognitive) capabilities of the crew of the navigation bridge exceed the problem-solving capabilities of the individual. ${ }^{68}$ He draws two sorts of distinctions, both based on the material conditions that he observed on the bridge. One distinction is based on the various technological tools that individuals relied on (for communication and for computation, for example); a second distinction was based on the social organization of the crew. Communication both reflected a particular social order and created it:

The social structure is not only the framework on which the communication is based, it is also the mechanism that is in place prior to the interactions to ensure that they take place as required. Why should the pelorus operator cooperate? Because adequate performance is the currency of social interaction. The novice quartermaster is institutionally located in such a way that his actions can be taken both as contributions to the process and as claims to or justifications of membership in the social world of other quartermasters. ...

....

It is clear that when quartermasters report bearings, assign landmarks, or ask for data, they are not just constructing position fixes; they are also constructing social relationships. And the fact that their respective responsibilities are so well specified does not eliminate the possibility of loading social messages into the communication acts that make up the work. In fact, the well-formed expectations about what

66. See generally David N. Perkins, The Possibility of Invention, in The NATURE OF CReativity: Contemporary Psychological PerspeCtives 362-85 (Robert J. Sternberg ed., 1988).

67. Edwin Hutchins, Cognition In the WiLd (1995).

68. See id. at 226. 
constitutes competent verbal behavior in this setting may give the participants an especially subtle means of communicating social messages. ${ }^{69}$

Hutchins characterizes this cognitive processing system as "distributed" or "decomposed," and he identifies a variety of benefits (and some costs) associated with it. By breaking down or "modularizing" cognitive tasks, it controls the complexity of the overall problem. It permits each individual to focus only on a relatively limited set of data, making that person's task more tractable. It facilitates the entry of novice practitioners into the system, by giving them social and other material structures that constrain them in their performance. It mitigates the consequences of a failure in some part of the system, so that the failure is not catastrophic. And it facilitates the adaptation of the system to change, particularly incremental or progressive change. ${ }^{70}$

One of Hutchins's special interests lies in how the social construction of cognition not only helps navigators solve problems, but also helps them to innovate in circumstances not governed by standard protocols. His conclusion, that " $[\mathrm{t}]$ he very same processes that constitute the conduct of the activity and that produce changes in the individual practitioners of navigation also produce changes in the social, material, and conceptual aspects of the setting," themselves in changes to the details of navigation practice, is supported by an example drawn from what he characterizes as the "cognitive ecology" of the bridge that supports cultural innovation: ${ }^{72}$ two members of the navigation team, the "plotter" and the "bearing recorder," innovate "a new concept and a shared lexical label for it (the "total' in the modular form of the true-bearing computation)." ${ }^{.73}$ It cannot be said on the basis of this observation that social structures of this (or any) sort are necessarily innovative or creative, but the finding does encourage paying attention to the social and cultural conditions that constrain and produce innovation, rather than solely to mental processes of one sort or another.

These results are at least suggestive in relatively well-defined problemsolving contexts, where the material structures involved are hierarchical and roles are clear. Hutchins, however, intends to draw a lesson that does not depend on the precise material conditions that he found in the Navy-that formal models of human cognition that are based exclusively on individual

69. Id. at 225 .

70. See id. at 226-28.

71. Id. at 374 .

72. See id. at $343-51$.

73. Id. at 374. Hutchins also describes the details of the episode. See generally id. at $317-42$. 
symbol-processing are necessarily and inherently flawed, ${ }^{74}$ because they necessarily omit the fact that, "in the wild," cognitive processing involves humans acting upon symbols, rather than the symbols alone, in themselves. ${ }^{75}$ As human agency is inextricably bound up with social and cultural conditions, cognition becomes a sociocultural system, rather than a function of an individual symbol processor.

I take two points from Hutchins's research, even assuming that his and others' work on distributed and embodied cognition is still in its early stages. The first is the affinity between Hutchins's diagnosis of the fundamental mismatch between classic models of cognitive processing, and his notion of "embodied" cognition, on the one hand, and my suggestion above that the law may err by channeling group activity into certain specified forms, on the other hand. The second is that if Hutchins is correct regarding cognition as a sociocultural system, the material conditions of informal groups, like those of the more formal social structures that Hutchins observed, are likely to participate in a "cognitive ecology" of adaptive and innovative practice. The characteristics of those practices are likely to be highly context-specific and therefore demand careful attention. By the same token, it would be unwise for law and policy to overlook their possible benefits.

\section{Constructive Groups}

A third and final example of the virtues of informed groups comes from the Science, Technology, and Society (STS) literature, which in broad terms analyzes technology and material culture as expressions of various social and normative commitments, rather than as "inevitable" products of material progress, as the fruits of purposive and functional design, or as manifestations of the true or authentic character of things. Technology is cultural, it has meaning, and that meaning is constituted by social and cultural forms, that is, by groups. We define the things we make, have, and use.

An example of this approach, and one that relies particularly clearly on informal groups, is the Social Construction of Technology, or SCOT, theory

74. Hutchins notes:

The system of ship navigation that I have presented in this book is based on formal manipulations of numbers and of the symbols and lines drawn on a chart. It is a system that exploits the powerful idea of formal operations in many ways. But not all the representations that are processed to produce the computational properties of this system are inside the heads of the quartermasters. Many of them are in the culturally constituted material environment that the quartermasters share with and produce for each other.

Id. at 360 .

75. See id. at 359-72. 
of Wiebe Bijker and his colleagues. ${ }^{76}$ Bijker describes the meaning of a given technological artifact as a function of various social groups, and a technological frame.

The phrase ["social group"] is used to denote institutions and organizations (such as the military or some specific industrial company), as well as organized or unorganized groups of individuals. The key requirement is that all members of a certain social group share the same set of meanings, attached to a specific artifact. ${ }^{77}$

The group exists both for group members, that is, people aware of being part of a group, and for observers, who reconstruct the existence of the group. (Groups may, but need not, consist of user populations.) Artifacts are introduced with, or develop, interpretive flexibility. Various groups develop different meanings via their interactions with it and with each other. Via an interative process, a dominant or stable meaning emerges, which Bijker calls its "technological frame.", "Ongoing interactions with an artifact, within and between relevant social groups, results in the creation of a technological frame that bounds the attributions of meanings by relevant social groups." 79 That frame hardens the artifact in a stable network of practices, theories, and institutions. The technological frame of the artifact, in turn, defines the boundaries of the group.

Bijker illustrates this process with descriptive histories of the bicycle, and of the plastic known as Bakelite:

A new technological frame is formed, shared by several social groups that until then could be represented by separate frames. The formation of the Bakelite frame through the enrollment of automotive engineers and radio amateurs is an example. Bakelite had an increasingly fixed meaning when it was used in the negotiations between employees of the General Bakelite Corporation and the engineers of the automobile, radio, and chemical instrument manufacturing industries. The artifact Bakelite thus functioned at the same time as an element in [the inventor] Baekeland's micropolitics of power and as a boundary artifact in the emerging semiotic power structure of the new Bakelite technological frame. We might say that Bakelite was a form of

76. See Wiebe E. Bijker, Of Bicycles, Bakelites, and Bulbs: Toward a Theory of Sociotechnical Change (1995); Trevor J. Pinch \& Wiebe E. Bijker, The Social Construction of Facts and Artifacts: Or How the Sociology of Science and the Sociology of Technology Might Benefit Each Other, in The Social Construction of Technological Systems: New Directions in the Sociology and History of Technology 7 (Wiebe E. Bijker et al. eds., 1987) (originally published at 14 Soc. STUD. OF SCI. 339 (1984)). SCOT theory is critiqued and extended in Ronald Kline \& Trevor Pinch, Users as Agents of Technological Change: The Social Construction of the Automobile in the Rural United States, 37 TeCh. \& Culture 763 (1996).

77. Pinch \& Bijker, supra note 76, at 30 ; see also BIJKER, supra note 76 , at 45-53 (describing the characteristics of groups).

78. See Pinch \& Bijker, supra note 76, at 30-39.

79. BIJKER, supra note 76, at 282. 
currency, allowing the negotiation of new relationships between previously unrelated social groups. The boundary artifact Bakelite helped to link, in an almost physical sense, the different social groups into one new semiotic structure. ${ }^{80}$

As a boundary, the artifact helps to define the group itself. Group insiders tend to view the artifact as unambiguous and constraining, but also as capable of differentiation, and therefore highly enabling. Outsiders tend to look at the artifact as monolithic, with a "take-it-or-leave-it" character. Making the "take it" choice means passage to the inside, a fact that links the sociocultural evolution described by SCOT to power dynamics and strategic behavior. ${ }^{81}$ In a real sense, the technological frame, connected to a social group, determines what the thing "is," and the character of the thing in turn helps to determine the shape and power of social groups.

I introduce Bijker, as I have introduced Cover and Hutchins, not to make a strong claim regarding the truth of these conclusions, or any one of them. I introduce them to illustrate how the notion of the informal group has been deployed as an analytic tool, with some explanatory power, in a variety of contexts. In none of these theories is the group introduced to serve a functional role; rather, each of them identifies the existence of the group and articulates ways in which the concept contributes to some broader understanding of social welfare. That is, we do not know in advance what or how any particular group will develop or the particular good or goal that it might achieve. In all three contexts summarized above, groups happen, and we can draw out their benefits after the fact. Those contexts are themselves intriguing for purposes of drawing parallels to legal analysis; SCOT theory is useful, for example, in understanding the normative power of the "substantial noninfringing use" doctrine that protects manufacturers of the VCR from secondary liability for copyright infringement. ${ }^{82}$

\section{GRoups IN THE LAW}

The good of groups should not be limited to the contexts described in Part II. This Part advances the argument one final step. If it is the case that informal groups may do good things, but we cannot specify in advance what those things are (if we could, then we would not have much use for the group concept, and we could focus on those things themselves), perhaps law and policy should look for ways to promote the informal group as such.

80. Id. at 283 .

81. See id. at 283-85.

82. See Sony Corp. of Am. v. Universal City Studios, Inc., 464 U.S. 417, 428, 437-38 (1984). 
There are at least two ways to promote the informal group. One is to do so directly, by declaring that some collective "is" or "is not" a group. This is the classical legal approach: A collective is a "city," or a "corporation," or a "jury," or a "family," because the collective satisfies certain formal conditions. $^{83}$ This is straightforward goal-oriented regulation; one might characterize it as a way for policy to secure the benefits of tightly integrated groups, and to mitigate their negative effects. ${ }^{84} \mathrm{~A}$ second way is indirect, by focusing on the material or structural conditions that support the formation and evolution of more loosely integrated groups, whose internal workings are left largely beyond the reach of the law. ${ }^{85}$ The distinction tracks what one recent article characterizes as the emergence of a "governance" paradigm for law and policy ${ }^{86}$ The policy challenge is not to divide the world into "public" and "private" (or "government" and "market") domains, or "social" and "private" spheres. Instead, the challenge is to understand the benefits of blending those traditionally distinct categories.

Identifying these material conditions means that I need to press a little harder on the core concept. What, precisely, is this loosely integrated, informal group? If informal groups as such have a potentially significant role in creating law and other social and technical goods, then it is important both to be able to recognize them, and to know when and how they are likely to arise. In both senses, law and policy can exercise an important role in influencing the creation of informal groups, and in sustaining them.

As I use the term, "informal group" is a broad and inclusive concept, embracing everything from quilting clubs to college alumni populations. It is broader and more inclusive than "team," "social network," or "community"-

83. The proposition that a collective is a "church" has run into difficulty in recent years, since law has been reluctant to establish formal criteria for what constitutes a genuine organized religion. See, e.g., O Centro Espirita Beneficiente Uniao Do Vegetal v. Ashcroft, 389 F.3d 973 (10th Cir. 2004), aff'd and remanded sub nom. Gonzales v. O Centro Espirita Beneficiente Uniao Do Vegetal, 126 S. Ct. 1211 (2006).

84. One well-established negative by-product of the tight-knit group is what psychologist Irving Janis labeled "groupthink," the tendency of members of cohesive groups to display strong "we-feelings" of solidarity and to maintain relationships within the group, at the cost of independent and critical thinking. See generally IRving L. JANIS, Victims OF GroupthinK: A Psychological Study OF Foreign-Policy Decisions AND Fiascoes (1972). Internally homogeneous small groups may nonetheless be more effective than their heterogenous counterparts in accomplishing specific tasks. See Marvin E. Shaw, A Note Concerning Homogeneity of Membership and Group Problem Solving, 60 J. ABNORMAL \& Soc. Psych. 448 (1960). But see Jeanne Longley \& Dean G. Pruitt, Groupthink: A Critique of Janis's Theory, 1 Rev. Personality \& Soc. Psych. 74 (1980).

85. Cf. OSTROM, supra note 35, at 12-21 (outlining conditions for successful commons management in structural terms).

86. See Lobel, The Renew Deal, supra note 1, at 365-67. 
the last term being of special interest both in the context of early cyberspace utopianism ${ }^{87}$ and in the context of research on social norms as governance structures ${ }^{88}$ Informal groups may or may not be close-knit "communities"; they may, in fact, be diverse, decentralized, and populated by people who are, for many purposes, acting independently of one another. (To some extent, that description tracks the concept of the social network, though I avoid that term largely because I am not borrowing network theory as an analytic tool. $)^{89}$ A group is bounded in some way, culturally, socially, or materially-it may be bounded by geography, territory, or other place; by discipline or practice; by membership, identity or interest, among other things-but that boundedness is neither fixed nor firm. ${ }^{90}$ Informal groups, as I conceive them, are not limited to small groups or to groups that are sanctioned or recognized by formal but non-legal rules. As I argued above, ${ }^{91}$ salience itself may serve to enforce a stable boundedness that identifies a group.

\section{A. Finding Groups in the Law}

Groups are, of course, partly an express target and partly an implicit byproduct of conventional legal regulation. For examples, I return to the law and policy of Internet technology. My emphasis on borders and boundedness echoes early debates in the cyberspace law literature regarding when and

87. See RHEInGOLD, supra note 45.

88. See generally Robert C. Ellickson, Order Without Law: How Neighbors SETTLE Disputes (1991).

89. Network theory focuses on one-to-one communications; my sense of groups is that their communication patterns may include one-to-many and many-to-many communications as well. For a specific borrowing of social network theory for legal policy, see Lior Jacob Strahilevitz, A Social Networks Theory of Privacy, 72 U. CHI. L. REV. 919 (2005).

90. See Stanford M. Lyman \& Marvin B. Scott, Territoriality: A Neglected Sociological Dimension, 15 Soc. ProBs. 236 (1967) (referring to boundaries of small social groups in public places as "social membranes"); Eric S. Knowles, Boundaries Around Group Interaction: The Effect of Group Size and Member Status on Boundary Permeability, 26 J. PERSONALITY \& SOC. PSYCH. 327, 330-31 (1973); see also sources cited supra note 17; Crawford, supra note 12, at 703 (The article describes borders and filters governing Internet information flow as "permeable" membranes. "They are . . the means by which individuals and groups govern dialogue, communication, flux, and flow. What we pay attention to defines who we are."). Related fluid definitions of groups include Clayton P. Gillette, The Path of the Law Today: Lock-in Effects in Law and Norms, 78 B.U. L. REV. 813, 839 (1998) (groups as norm-based); Eric A. Posner, The Regulation of Groups: The Influence of Legal and Nonlegal Sanctions on Collective Action, 63 U. CHI. L. REv. 133, 135 (1996) (groups as cooperation-based); Edward L. Rubin, Images of Organizations and Consequences of Regulation, 6 THEORETICAL INQUIRIES L. 347, 363 (2005) (groups as culture-based).

91. See supra note 17 and accompanying text. 
whether "cyberspace" should be characterized as an independent legal jurisdiction. To what extent should online activity identify its participants as members of a distinct normative group? In doctrinal terms, the debate has been manifested in decisions applying national norms for personal jurisdiction. The traditions of the field dictate that the question be framed as one of jurisdiction to adjudicate the interests of an individual defendant, but, as Paul Berman points out, the personal jurisdiction construct may be reconceptualized in terms of the authority of competing sovereigns, i.e., informal groups: "[T]he story of jurisdiction is a story of social space and community definition[, in which] the very ideas of space and community are themselves narrative constructions that are always contested." 92

Group identity and affiliation raise questions of insider and outsider status-Is a person genuinely part of the group? Is that person entitled to come in, or to be here?-that track other doctrinal issues. Cases addressing unauthorized use of computer network resources, whether based on "trespass to chattels" doctrine, ${ }^{93}$ the Digital Millennium Copyright Act,${ }^{94}$ or "clickwrap" and related contract claims, ${ }^{95}$ are determined in part by analysis of individual interests, but also by policy judgments regarding the scope and value of claims to authentic in-group status. The question in each case is the extent to which the owners and operators of some computer network are entitled to determine for themselves the scope and content of the group that comprises the network. eBay gets to determine who "is" eBay, for example; ${ }^{96}$ the terms of the open source software license determine the scale and the character of the open source software community. ${ }^{97}$ Governance of the group raises the question of dynamism. How are the evolutionary processes of the group to be governed? Doctrinally, can the proprietors of a "group" defined by license (such as a community of software users) and/or software (such as an online game environment) create a baseline for group dynamics that mandates the perpetuation of the group (as in the case of the open source software license) or that excludes that right to reverse engineer the software platform itself-that is, to evolve the group? (2002)

92. Paul Schiff Berman, The Globalization of Jurisdiction, 151 U.PA.L. REV. 311, 490

93. See eBay, Inc. v. Bidder's Edge, Inc., 100 F. Supp. 2d 1058 (N.D. Cal. 2000).

94. See Davidson \& Assocs., Inc. v. Jung, 422 F.3d 630 (8th Cir. 2005).

95. See Register.com, Inc. v. Verio, Inc., 356 F.3d 393 (2d Cir. 2004).

96. I do not mean to suggest that the cases line up uniformly in favor of this result, but it is a standard that can be used to differentiate the cases. The scope of a group's claim to selfdetermination is contestable.

97. See Michael J. Madison, Reconstructing the Software License, 35 LOY. U. CHI. L.J. 275 (2003) (analyzing the character of open source software licensing as a governance regime). 
Cases involving online anonymity and defamation similarly query the legitimacy of claims of group affiliation. To what extent does membership in a group require disclosure of individual identity-either inside or outside the group $?^{98}$ Relatedly, how should reputation, which is always a group question of some sort, be managed online? ${ }^{99}$ Investigations of online identity may be characterized, therefore, as investigations of groups themselves. Susan Crawford sums up the question with the phrase, "Who's in charge of who I am?" ${ }^{100}$ However desirable we think anonymity and pseudonymity are in the real world, to what extent should that sense extend online? To what extent should anonymity and pseudonymity be enabled by law and technology? ${ }^{101}$ If the ability to deceive regarding your identity is a valuable characteristic of some groups, how do we balance that interest against legitimate interests in protecting reputation, both within those groups, and outside them? ${ }^{102}$

Similar exercises, to constitute doctrinal questions as inquiries into informal groups, might be pursued in the context of privacy law, ${ }^{103}$ intellectual property and speech law, ${ }^{104}$ and corporate law. ${ }^{105}$ In the balance of this Part,

98. See Jerry Kang \& Benedikt Buchner, Privacy in Atlantis, 18 HARV. J.L. \& TECH. 229 (2004) (fleshing out a "constitutive" theory of privacy as an alternative to autonomy and dignity theories).

99. See Susan Freiwald, Comparative Institutional Analysis in Cyberspace: The Case of Intermediary Liability for Defamation, 14 HARV. J.L. \& TECH. 569 (2001) (applying comparative institutional analysis to the question of the appropriate legal standard for online intermediaries that distribute defamatory content).

100. Crawford, supra note 30.

101. See John Alan Farmer, Note, The Specter of Crypto-Anarchy: Regulating Anonymity-Protecting Peer-to-Peer Networks, 72 FordHAM L. REV. 725 (2003).

102. See Lyrissa Barnett Lidsky, Silencing John Doe: Defamation \& Discourse in Cyberspace, 49 Duke L.J. 855 (2000).

103. Privacy concerns raised by online data collection and disclosure are closely linked to the sense that data might associate us with, or distinguish us from, one or more groups. Daniel Solove calls this the "aggregation" problem. Daniel J. Solove, Access and Aggregation: Public Records, Privacy and the Constitution, 86 MinN. L. REV. 1137, 1184-95 (2002). Lior Strahilevitz takes the opposite view, that privacy is not a function of the consolidation of information, but of the likelihood that it will be distributed. See Strahilevitz, supra note 89 (arguing that privacy is a function of the connectedness of the group, i.e., the likelihood that information about you is likely to become known within, and beyond, some group). In either case, privacy depends how we conceptualize group context.

104. See generally Jerry Kang \& Dana Cuff, Pervasive Computing: Embedding the Public Sphere, 62 WASH. \& LEE L. REV. 93 (2005); McGowan, Social Friction, supra note 52.

105. I use the label "corporate law" to describe work on institutions designed to support production of goods and services. See, e.g., Benkler, supra note 43; Margaret Chon, New Wine Bursting From Old Bottles: Collaborative Internet Art, Joint Works, and Entrepreneurship, 75 OR. L. REv. 257 (1996); Hunter \& Lastowka, supra note 48. While the Internet has demonstrated that there are viable alternatives to the firm in coordinating production of goods, those alternatives need not (and probably should not) be characterized solely in terms of 
however, I turn to tools that law may use to manipulate the material conditions that nurture informal groups and, in turn, to press on the doctrinal questions just reviewed. If informal groups are defined by their loosely bounded character, and salience enhances a sense of boundedness, then law and policy should seek out ways to enhance that salience. Some recent research in organizational behavior suggests, in fact, that using indirect tactics to heighten the salience of various material features of the social environment is likely to enhance productive informal group dynamics, and that direct or "controlling" regulation of the group is likely to limit the effectiveness of the group. ${ }^{106}$ Below, I describe three such tools.

\section{B. Law and The Future of Groups}

In Part II, I described three contexts in which theorists posit the good that groups might do, contexts that might be reduced, crudely, to stories (Cover's group-dependent nomos), places (Hutchins's navigation bridges), and things (Bijker's material artifacts). Drawing out the salience of informal groups, then, might take at least these three forms: orienting activity toward or around things, reinforcing a sense of place, and heightening the boundary characteristics of relevant narratives. ${ }^{107}$ In the discussion that follows, I draw liberally on my earlier work.

\section{On Things ${ }^{108}$}

Groups both create and depend on things. As Wendy Gordon has noted, "Shareable goods are a traditional source of binding groups together: not only standard 'public goods' such as highways and defense, but also folk tales, art, songs, and symphonies." 109 Beth Noveck observes that online groups depend

enhanced individual agency.

106. See Mark Thompson, Structural and Epistemic Parameters in Communities of Practice, 16 ORG. SCI. 151, 161-63 (2005).

107. Steven Johnson describes a comparable intersection in STEVEN JOHNSON, Interface Culture: How New Technology Transforms the Way We Create and COMMUNiCATE 11-14 (1997), in which he relates information spaces, stories, and things in medieval architecture, nineteenth-century literature, and software interfaces.

108. The material in this Subpart is drawn in part from Michael J. Madison, Law as Design: Objects, Concepts, and Digital Things, 56 CASE W. RES. L. REV. (forthcoming 2006).

109. Wendy J. Gordon, Intellectual Property, in OXFORd HANDBOOK OF LEGAL STUDIES 617, 644 (Peter Cane \& Mark Tushnet eds., 2003). 
on stable representations of group members and group-related objects. ${ }^{110}$ Property rights, as things, reify relationships between and among people.

In each of these senses, groups coalesce around things. These may be physical, tangible things. They may be intangible or virtual things. Thomas Schelling described the concept of "focal points," now sometimes referred to as "Schelling points," to describe objects or sites around which individuals coordinated their activities. ${ }^{111}$ STS scholars refer to "affordances" of objects in the physical world to denote the role that objects play in shaping how individuals behave and how group dynamics evolve. ${ }^{112}$ Customs, traditions, patterns, and practices of reproduction, modification, and use develop and intersect via connections to things. ${ }^{113}$ Communications channels develop to discuss, respond to, and simply to use things. Things embody information that communities and groups develop, deposit, and extract. ${ }^{114}$ Via their very shape and via their classification in law or otherwise, things exercise authority. Social software is a thing. An open source software program is a thing. An open source license is a thing. A weblog is a thing; a wiki is a thing; a

110. See Noveck, supra note 12; see also Barbara Tversky \& Paul U. Lee, How Space Structures Language, in 1404 LeCture Notes in COMPUTER SCIENCE: SPATIAL COGNITION, AN InTERdisciplinary ApProach to Representing and Processing Spatial KNOWLEdge 157, 163 (Christian Freska et al. eds., 1998) (describing how salience, permanence, and proximity of objects influence patterns of work relationships).

111. See generally Thomas C. Schelling, The Strategy of Conflict (1960). Schelling Points are defined by reference to problem-solving and game theory, not space in particular. But they help to illuminate the problem of coordination without communication. In spatial problems, a Schelling Point is an informal location where people are likely to meet each other. They play roles similar to landmarks in navigation. See also M.E. Sorrows \& S.C. Hirtle, The Nature of Landmarks for Real and Electronic Spaces, in 1661 LECTURE NOTES IN Computer Science: Spatial Information Theory: Cognitive and Computational Foundations OF GEOGRAPHIC INFORMATION SCIENCE 37 (Christian Freska \& David M. Mark eds., 1999).

112. See Donald A. Norman, Things That Make Us Smart: Defending Human Attributes in the Age of the Machine 243 (1993).

113. Aafke Komter captures this point:

How do things come to embody meaning? In much anthropological and sociological writings, things have mainly been considered in two ways: either as commodities or as gifts. Correspondingly, people's relationships to things and to other people seem to fall in two broad categories, often regarded as mutually exclusive: either as impersonal, economic or market relationships with strangers, or as personal gift relationships with intimates, friends or relatives. The "social life of things", however, is more varied.

Aafke Komter, Heirlooms, Nikes and Bribes: Towards a Sociology of Things, 35 Soc. 59 (2001).

114. See Hanoch Dagan \& Michael A. Heller, The Liberal Commons, 110 YALE L.J. 549, 609-11 (2001) (recommending property forms that create incentives for the sorts of cooperation that occur within strong communities); Peñalver, supra note 13. 
network is a thing. We recognize them as things, think of them as things, and speak of them as things.

Patents, for example, are things that are entirely legal creations, and though they are not "social software," patents coordinate systems of activity, and do so quite explicitly, in much the way that social software does in other domains. ${ }^{15}$ Even more clearly, the characteristics of the open source computer program and the open source software license, or the Creative Commons license and the Creative Commons-licensed work, so long as they are suitably salient, are hubs for groups of various sorts. ${ }^{116}$

If things have a potentially authoritative role in constituting groups, law and policy can work on enhancing their salience and stability. Things occupy their social role via their presence and relative permanence, but things are not simply given. They are created, and they evolve. Law has quite an elaborate set of mechanisms that it uses to create and manage "thing-ness." Sometimes the law reinforces thing-ness, by increasing the hard-edges of copyrights and patents, or software licenses that coordinate group activity, for example. Sometimes the law disables or moderates it, by loosening those edges with exceptions and limitations. The STS tradition in which Bijker is writing, which is especially attentive to changes in things over time, would recommend situating thing-ness by referring to practices ("how things are used"), and that approach is well-represented in law. But law also manages thing-ness by referring to economics ("the welfare effects of things"), in bargains and contracting (via clickwrap agreements, the parties agree on what a "thing" "is"), to design ("it's just the way things are"), or to the essential properties of the object ("the natural order of things"). The point here is that the law has regulatory options.

\section{On Places ${ }^{117}$}

Groups do not depend solely on things; groups also depend on place, or at least on a sense of place. Sociologists and geographers are acutely aware

115. This is one way to interpret Edmund Kitch's "prospect" theory of patenting. See Edmund W. Kitch, The Nature and Function of the Patent System, 20 J.L. \& ECON. 265, $275-$ 80 (1977) (arguing that patents allow the coordination of follow-on investment in innovation); see also Jay P. Kesan \& Rajiv C. Shah, Deconstructing Code, 6 YALE J.L. \& TeCH. 277 (2003-2004) (discussing the governance characteristics of computer code and the interrelationship between the social characteristics of the development environment and the governance characteristics of the product).

116. See Madison, supra note 65, at 282-85, 290-95.

117. The material in this Subpart is drawn in part from Michael J. Madison, Rights of Access and the Shape of the Internet, 44 B.C. L. REV. 433 (2003). 
of the role of place and its cousin, space, in ordering activities of groups. ${ }^{118}$ Individuals want and need to know where they are, and where others are, in order to manage various communicative practices. ${ }^{119}$ This relationship flows in the opposite direction as well. Critical geographers point out that places derive their character from the social practices situated there. ${ }^{120}$ Place and space structure social relationships, and are structured by them.

In the physical world, Jane Jacobs, Lewis Mumford, and others pointed out long ago the extent to which we take space and place for granted, and the extent to which we can manage our environment to produce and support different kinds of social interaction. The physical affordances of place and space can enliven and stimulate a group, or deaden it. ${ }^{121}$ Architects and

118. There is a vast literature on how various attributes of place and space, including distance, "adjacence," and permanence, support and instantiate social relations within and among groups. See, e.g., William J. Mitchell, City of Bits: Space, Place and the Infobahn (1995); Dolores Hayden, The Power of Place: Urban Landscapes As Public History (1995); Lee Cuba \& David M. Hummon, A Place to Call Home: Identification With Dwelling, Community, and Region, 34 Soc. Q. 111 (1993); Jerry Frug, The Geography of Community, 48 Stan. L. Rev. 1047 (1996); Thomas Gieryn, A Space for Place in Sociology, 26 ANN. REV. Soc. 463, 463-96 (2000).

119. See, e.g., Roger A. Hart \& Gary T. Moore, The Development of Spatial Cognition: A Review, in Image and Environment: Cognitive Mapping and Spatial Behavior 246, 248 (Roger M. Downs \& David Stea eds., 1973) (describing spatial cognition as the cognitive representation of the structure, entities, and relations of space, including how space structures actions and interactions among members of a team); EDWARD T. HALl, THE HIDDEN DiMENSION (1966) (describing the social use of space as the practice of "proxemics," borrowing from "proximity" as the most important social feature of space). Similar uses of space and distance to police social interactions are observed in online settings in Barbara Becker \& Gloria Mark, Social Conventions in Collaborative Virtual Environments, in ProceEdings of CVE ‘98, Conf. on Collaborative Virtual Environments (Elizabeth Churchill \& David Snowdon eds., 1998), available at http://wwwcs.uni-paderborn.de/ bbecker/Becker98.1.pdf, and offline in Iris Bohnet \& Bruno S. Frey, The Sound of Silence in Prisoner's Dilemma and Dictator Games, 38 J. Econ. Behav. \& ORG. 43 (1999); A. Paul Hare \& Robert F. Bales, Seating Position and Small Group Interaction, 26 Sociometry 480 (1963); Elizabeth Hoffman et al., Social Distance and Other-Regarding Behavior in Dictator Games, 86 Am. ECON. REV. 653 (1996).

120. See Michelde Certeau, The Practice of Everyday Life (Steven Rendall trans., Univ. of Cal. Press 1988) (1974); David Harvey, Justice, Nature \& THe Geography of DifFerence (1996); David Harvey, Spaces of Capital: Towards a Critical Geography (2001).

$[\mathrm{I}] \mathrm{t}$ is no longer possible to understand "place" in static terms or from any singular vantage point. As cultural geographers have shown, places are not sources of stability-the source of essential or integrated identities-around which boundaries can be drawn, but are particular constellations of historical relations articulated at a particular locus.

Rosemary J. Coombe, The Cultural Life of Things: Anthropological Approaches to Law and Society in Conditions of Globalization, 10 AM. U. J. INT'L L. \& POL'Y 791 (1995).

121. See generally Jane Jacobs, The Death and Life of Great American Cities 
planners can do this through design; law, too, can do it by rewarding features of the physical environment that signal the presence of bounded places. ${ }^{122}$ The urban planner Kevin Lynch demonstrated this in The Image of the City, ${ }^{123}$ concluding that inhabitants of a city relied on mental "readings" of their cities, focusing on landmarks and boundaries: "[I]f the environment is visibly organized and sharply identified, then the citizen can inform it with his own meanings and connections. Then it will become a true place, remarkable and unmistakable." ${ }^{24}$ The organization and distinction derived from an inventory of features and boundaries that included open space, contrasts-paths, edges, nodes, landmarks, and distinct districts-and a sense of motion. ${ }^{125}$ The degree to which these features were present is a measure of the "imageability" of the environment, defined as "that quality in a physical object which gives it a high probability of evoking a strong image in any given observer. It is that shape, color, or arrangement which facilitates the making of vividly identified, powerfully structured, highly useful mental images of the environment."126 An "imageable" city conveys a coherent mental map to its inhabitants. ${ }^{127}$ In short, place is not simply a matter of where you are. Place is a cognitive construct.

There is no reason to think that a different proposition applies in virtual or online contexts, particularly given the extent to which our colloquial sense of those environments is framed by metaphors of place and space. ${ }^{128}$ The environmental heterogeneity and salience that Jacobs and Mumford praised can be developed online as well. One way to do that is through interface design, such that the apparent "physical" features of the online setting are sufficiently stable to signify "place" to the individuals who "go" and "stay" there. Law offers a complementary set of tools, which can be used to reward online "imageability." Boundaries, borders, and connections in computer networks may be omnipresent as a technical matter, but hidden, for all intents and purposes, from the perspective of those who use those networks. Law and

(1961); Lewis MuMford, The City IN History: ITS ORIGINS, ITS TRANSFORMATIONS, AND ITS Prospects (1961); see also Joseph Rykwert, The Seduction of Place: The History ANd FUtURE OF THE CiTY (2000).

122. See First Unitarian Church of Salt Lake City v. Salt Lake City Corp., 308 F.3d 1114, 1121 (10th Cir. 2002); Hotel Employees \& Rest. Employees Union Local 100 v. City of N.Y. Dep't of Parks \& Recreation, 311 F.3d 534, 544 (2d Cir. 2002).

123. Kevin Lynch, The Image of the City 2, 8-13 (1960).

124. Id. at 92 .

125. Id. at $16,46-49$.

126. Id. at 9 .

127. See id. at 108-10.

128. See generally Dan Hunter, Cyberspace as Place and the Tragedy of the Digital Anticommons, 91 CAL. L. REV. 439 (2003). 
policy may intervene to promote the salience of those boundaries and borders in a variety of doctrinal settings. Purported acceptances of offers of clickwrap agreements and "terms of use" may be deemed ineffective if the offers were not sufficiently visible; "technological protection measures" that trigger application of the anti-circumvention provisions of the Digital Millennium Copyright Act may be deemed "ineffective" if the user is not sufficiently warned of their existence; the doctrine of "trespass to chattels" may not be invoked by the owner of an online data resource unless the boundary that the defendant has crossed is marked in some clear, human-readable way. ${ }^{129}$ The law has not, generally, moved in this direction, but it is clear that doctrinal tools exist to implement the policy choice.

\section{On Stories ${ }^{130}$}

The conventional account defines groups by their goals. We encourage individuals to do things in groups when we like what groups do; we discourage individuals from participating in groups when we do not like what groups do. At the far edges of the normative spectrum, this is inescapable. A terrorist cell is a group of a sort that almost anyone would agree has no defensible normative basis. ${ }^{131}$ A nuclear family or a household is the sort of group that almost anyone would agree has a nearly impeccable moral pedigree. ${ }^{132}$ In the vast middle, however, lies the unexplored normative territory of groups. To help us make sense of this territory, law and policy may need yet another set of tools, this one drawn from literature. We can succeed in differentiating good groups from evil groups, and better groups from worse groups, in part, by explaining, exploring, and contrasting the narratives that can be constructed out of them. ${ }^{133}$ Social software shows how

129. See Madison, supra note 117 , at 492-502.

130. The material in this Subpart is drawn in part from Michael J. Madison, The Narratives of Cyberspace Law (or, Learning from Casablanca), 27 COLUM. J.L. \& ARTS 249 (2004).

131. Of course, we still very much want to understand how terrorist cells develop and operate, and we want to understand how to distinguish illegitimate "terrorism" from legitimate armed struggle. See The Legitimization of Violence (David E. Apter ed., 1997).

132. The household, too, constitutes a group with a complex external structure and relationship to the outside world. See, e.g., Robert C. Ellickson, The Household: The Law, Economics, and Sociology of an Underexamined Institution (Apr. 3, 2003), http://www.people .hbs.edu/gbaker/oes/papers/Household_Harv_MIT.pdf.

133. See generally Rubin, supra note $\overline{90}$ (arguing that the effectiveness of regulation of firms depends on our images of organizational behavior in the corporation); Zittrain, supra note 49 (characterizing an important benefit of the Internet as allowing people to collaborate on the creation of meaning). 
groups themselves can propose and evolve their own narratives. Virtual worlds technology consists, at one level, of nothing but story creation.

We might, alternatively, use narrative techniques to construct stories as observers. Informal groups are social structures for communicating. They are social structures that involve sharing things-sharing identities, sharing information, sharing tangible stuff. The sharing may be the point, or the sharing may be a by-product. But sharing of one sort or another is involved. My examples from social software simply make the character of those sharing arrangements more explicit than they often are. Is sharing a good thing? That, then, is the difficult question, and my suggestion is that constructing persuasive narratives-something that the law can do-will help us to answer that question.

Where do we find these narratives, or how do we construct them? In a recent article on fair use in copyright law, I went through an analysis of economic, sociological, and anthropological literature on this point, and came to the tentative conclusion that patterns of social behavior may be oriented around particular disciplines or practices, such as journalism, or scholarship. Disciplines come with sets of rules, soft rules, certainly, but rules that are recognized both inside and outside the discipline, and which police the borders of the discipline and activity by its members. Professional disciplines are not the only sources of rules. Rules can be borrowed from outside contexts, or they can emerge from sustained interaction among individuals. They may be formal; they may consist of social norms; and/or they may consist of conventions or regularities in social behavior. My earlier work characterized these structures as "patterns," though one could borrow the phrase "practices" just as easily. ${ }^{134}$

These "rules of the game," so to speak, constitute narratives in themselves. If we find them, the law may conclude that it should privilege them. In the context of fair use, my claim is that the law has done just that, and that it is right that it should do so. Informal groups based on social practices are, I argue, inclined to be innovative and creative. ${ }^{135}$ The law need not go that far. Narratives of this sort carry the kind of persuasive potential

134. See Michael J. Madison, A Pattern-Oriented Approach to Fair Use, 45 WM. \& MARY L. REV. 1525, 1628-29 (2004).

135. See Mihaly Csikszentmihalyi, Creativity: Flow and the Psychology of Discovery and Invention (1996); George H. Mead, Mind, Self \& Society: From the STANDPOINT OF A SOCIAL BEHAVIORALIST (1934) (describing "the emergence of the novel" from social patterns); R. Keith Sawyer, The Emergence of Creativity, 12 PHIL. PsYCHOL. 447 (1999) (describing novelty as a necessary property of complex emergent systems); R. Keith Sawyer, Introduction, in CREATIVITY AND DEVELOPMENT (R. Keith Sawyer ed., 2003) (describing role of artifacts and domains in mediating dynamic relationship between individual and social processes). 
that we see throughout the law. A group sustained by a persuasive narrative may deserve greater deference in law and policy than a group without one. We see this, for example, in debates over the scope of secondary liability for copyright infringement. Twenty years ago, when the VCR was under challenge, "time-shifting" by VCR users created a narrative that ultimately persuaded the Supreme Court that sales of the VCR should not trigger liability. Defenders of contemporary P2P file-sharing networks have yet to develop a comparably persuasive narrative. ${ }^{136}$

Patent law offers another striking example of the development and application of a group narrative. Scholars looking at the sociology of science have recognized, anecdotally, that the optimal organization of scientific research consists of independent communities of researchers working with knowledge of one another's activities. ${ }^{137}$ Welfare costs from duplicative research are more than offset by correction of mistakes, confirmation of research results, and differential analyses of common data, leading to better syntheses. ${ }^{138}$ Pure "science," in turn, receives special dispensations in intellectual property law: "Laws of nature" (the objects of basic scientific research) are unpatentable; until recently, academic practitioners of patented technology could look to an "experimental use" exemption from liability for patent infringement. The fact that the experimental use exception appears to have been cut back dramatically, if not eliminated entirely, suggests the weakening of the "basic science" narrative on which academic scientists have long relied. ${ }^{139}$

136. See In re Aimster Copyright Litig., 334 F.3d 643, 652-53 (7th Cir. 2003) (noting the absence of genuine evidence of any legitimate use for file-sharing system), cert. denied sub nom. Deep v. Recording Indus. Ass'n of Am., 540 U.S. 1107 (2004).

137. See Rebecca S. Eisenberg, Patents and the Progress of Science: Exclusive Rights and Experimental Use, 56 U. CHI. L. REV. 1017, 1061, 1063-65 (1989) (citing Michael Polanyi, The Republic of Science: Its Political and Economic Theory, 1 Minerva 54, 56 (1962), and the various works of Robert K. Merton and Warren O. Hagstrom).

138. Robert Merton famously described "science" according to its norms of information disclosure and exchange. See Robert K. Merton, The Normative Structure of Science, reprinted in The Sociology of Science: Theoretical and Empirical Investigations 267, 270-75 (Norman W. Storer ed., 1973); see also Stephen Hilgartner \& Sherry Brandt-Rauf, Data Access, Ownership, and Control: Toward Empirical Studies of Access Practices, 15 KNOWLEDGE 355 (1994) (describing "datastreams" model of scientific research and information exchange). Carol Rose notes: "In whatever ways creative communities may be organized, the point remains that in many intellectual and artistic endeavors, creativity may be synergistic less with the world at large than with communities of other artists, creators, and contributors." Carol M. Rose, Romans, Roads, and Romantic Creators: Traditions of Public Property in the Information Age, LAW \& CONTEMP. ProbS., Winter/Spring 2003, at 89, 107.

139. See Madey v. Duke Univ., 307 F.3d 1351, 1360-61 (Fed. Cir. 2002). 
What role can law and policy play here, besides responding to these sorts of internal narratives? Disciplinary practices and normative communities are not the only sources of narrative. Advocates develop narratives to help their clients; policymakers develop narratives to advance agendas. The flexibility of cyberspace technology suggests that we can design our own group narratives as we use the technology to design groups themselves. ${ }^{140}$ This may be the ultimate virtue of social software: It allows its participants to create their own stories. The role of law, then, is to judge the extent to which it should allow this to happen. ${ }^{141}$ Social software may teach, then, that law does not need to discriminate between "good" groups and "bad" groups. Rather, whatever its regulatory goals may be, the law needs to develop tools to manage the development, maintenance, and evolution of rule structures that define groups themselves.

\section{CONCLUSION}

Internet and related communications technologies support an emerging environment of what I call "social software." "Social software" supports the creation and persistence of informal, dynamic groups of people, and it makes those groups visible and salient to a larger degree than they have been before. That salience should prompt law and policy to rethink historic skepticism of informal collectives, particularly in light of suggestions that the loose constraints that define informal groups may enable them to do a lot of good.

Amid my praise for the virtues of the informal group, in this Conclusion I hedge my bets. Much of this topic remains for further exploration, within law as well as within economics, sociology, and computer science itself. My caution stems from several sources. One is the nagging sense that we do not know enough about where groups come from and how they operate to entrust them with important chunks of public policy. Law and policy flirted with sociology and the notion of groups during the middle of the twentieth century. ${ }^{142}$ Over a period of decades it largely abandoned that discipline in

140. See Madison, supra note 130, at 256-59; Zittrain, supra note 49.

141. Susan Crawford argues that complexity theory teaches: "[W]e are more likely to get that optimal system if we allow communities and groups of all kinds to [define their own boundaries]," because that is likely "to permit the most valuable and interesting society to emerge." Crawford, supra note 12, at 743, 744. This, for example, is the question framed by the Grokster litigation: To what extent should the network(s) supported by the Grokster technology be allowed to evolve without legal interference? See supra note 18 and accompanying text.

142. For examples of recent scholarship noting the turn away from pluralism and toward individualism, see Dalia Tsuk, From Pluralism to Individualism: Berle and Means and 20th- 
favor of individualism and, ultimately, a growing reliance on neo-classical economics. If law is going to borrow from the social sciences, the question is which ones to choose? The economics paradigm has well-known weaknesses, but it is not clear that we know enough to turn away from it entirely. ${ }^{143}$

Alongside that descriptive concern is this normative one: Law's skepticism of informal groups may be well-founded, since, for purposes of the law, informal groups may create more problems than they solve. At the abstract level, if much of my argument may be reduced to the point that public policy should give informal groups broad discretion to organize and manage their own affairs, where and how do we locate limits for that discretion? Antitrust law is virtually the only resource that we currently have at our disposal, particularly as it deals with anti-competitive implications of technical standards and standard-setting organizations, and antitrust law is having a very difficult time with this sort of question. ${ }^{144}$ At the concrete level, how does a lawyer counsel a client regarding the benefits and hazards of

Century American Legal Thought, 30 L. \& SOC. INQUIRY 179 (2005), and Christopher L. Sagers, Antitrust Immunity and Standard Setting Organizations: A Case Study in the Public Private Distinction, 25 CARDOZo L. REV. 1393 (2004).

143. I note, however, that game theoretic approaches to groups have yielded insights that roughly parallel those that I have drawn from other social sciences. Robert Axelrod, in his seminal work Evolution of Cooperation, posited the existence of cooperative behavior based on norms of reciprocal altruism among group members. See AXELROD, supra note 35. Subsequent work has identified circumstances in which cooperative or coordinated activity within a group might arise in the absence of reciprocity, in the absence of altruism, and even in the absence of either one. See Ernst Fehr et al., Strong Reciprocity, Human Cooperation and the Enforcement of Social Norms, 13 Hum. NATURE 1 (2002) (noting the existence of norms of "strong reciprocity" in rewarding and punishing behavior among group members, even in the absence of norms of altruism); Michael Cohen et al., The Role of Social Structure in the Maintenance of Cooperative Regimes, 13 RATIONALITY \& SoC'Y 5 (2001) (arguing that social structures may explain emergence of cooperative behavior in groups that do not otherwise display repeat-play characteristics); Ernst Fehr \& Simon Gachter, Cooperation and Punishment in Public Goods Experiments, 90 AM. ECON. REv. 980 (2000) (noting that willingness to punish free riders, and to cooperate, increases as visibility of individual actions to other parties increases).

144. See, e.g., Andrew Chin, Decoding Microsoft: A First Principles Approach, 40 WAKE Forest L. ReV. 1 (2005) (arguing that Microsoft should have been found liable under any Sherman Act theory presented by the United States); David J. Teece \& Edward F. Sherry, Standards Setting and Antitrust, 87 MinN. L. REV. 1913 (2003) (arguing for greater deference to internal decisionmaking by standard setting organizations). An economic argument for a limiting principle appears in Brett M. Frischmann, An Economic Theory of Infrastructure and Commons Management, 89 MinN. L. REV. 917 (2005) (reducing the principle to the maxim, "if infrastructure, then commons"). The question of deference to group decisionmaking is not limited to informal groups, of course. 
dealing with informal groups? Consider a small company that is considering whether to install a computer program developed and maintained by an informal open source "community" and licensed under an open source software license. How does that company evaluate the commercial risks that may accompany using that program? With a firm as licensor, the lawyer can track its organizational structure and assess possible sources of liability and recovery. In the open source context, this problem is not insuperable, but it is considerably more complex, and both professional and economic incentives tend to push organizational forms toward the simpler solution. Prefer the individual, and prefer the firm.

That conclusion may offer a basis for caution in locating the future of the group in the law, but that caution does not take away from the core of my argument. Autonomy, it might be said, is overrated: The liberating potential of the personal computer is, in many respects, unfulfilled. In the home, computers are used as high-tech telephones and small-scale music studios. We email as much as we talk on the phone. We burn CDs and DVDs as much as we go to concerts or movie theaters. We surf the Web instead of going to the library and visit chat rooms instead of (or even inside of) the local coffee shop. In the workplace, today's low-level programming cube-farmers have little more "autonomy" than the human "computers" of fifty years ago. At an individual level, whether we are using computing technology to produce, or consume, or reuse, people are still "computers"; only the scale and distribution of processing power has changed. It is only something of a rhetorical overstatement to say that the "autonomy" granted by modern digital computing isolates and diminishes us at least as much as, if not more than, it brings forth our potential. Perhaps, then, to ask about computers and "autonomy," is, at least in traditional terms, to ask the wrong question. Sometimes we should look at the "I." But much of the time, we should be looking at the "we." 